\title{
USING SELECTED PERSONALITY VARIABLES IN A LEARNING PROCESS FOR HOLISTIC EDUCATION: A CASE OF A VOICE TRAINING COURSE PARTICIPANTS
}

\author{
Katri-Liis Vainio, Rea Raus \\ Tallinn University, Estonia \\ E-mail: katriliis@luukku.com, rearaus@tlu.ee
}

\begin{abstract}
This article aims to find ways to support a learner in a holistic manner, applying Myers-Briggs Typology Indicator (MBTI) as a methodological tool to facilitate learning process by considering learner individualities. Suggestions how to use MBTI in short-term courses of adult training, concentrating on feedback, performance, communication needs are made, based on the results of a study conducted among participants of the voice training. As the MBTI results can be understood and grouped in several ways, this study also compared the results with 3 different versions: Hanson \& Silver (1995), Schroeder (1993) and Keirsey \& Bates $(1978,1998)$ findings. Results were found matching most to the findings of Hanson $\&$ Silver (1995). This study reveals the typology of learners as Introverts and Extroverts, Analytical Thinkers, Social-Reflective Feelers and Holistic Visionaries. Although the research gives only preliminary conclusions, it gives certain recommendations how to approach different learners during the learning process.
\end{abstract}

Key words: adult learning, learner individualities, ecological paradigm, MBTI, voice training.

\section{Introduction}

\section{Problem of Research}

Educators find themselves often facing a problem how to best consider learner individualities during a learning process, especially in the case of solitary lectures or short-term courses. In such cases, the contact time for an educator and a learner maybe limited to a couple of meetings.

Therefore, the main aim of the study was to find ways how to help educators enhance learning in short-term courses, taking into consideration learner individualities.

The present article defines educators as professionals who are engaged in teaching activity i.e. classroom teachers, university teachers, training facilitators etc. Everyday practice shows that an educator must think about reaching a maximum learning result with sometimes the minimum of time. In this study psychometric questionnaire MBTI was used as a (1) tool of reflection to help educators to understand their learners better and take learner individuality into consideration during learning process (Lyons 1984; Thompson \& Borrello, 1986; McNickle \& Veltman 1986; Clark \& Peterson 1986) and (2) to help learners to gain important self-awareness (Fitzgerald 1997; Hammer 1996; Myers, McCaulley, Quenk \& Hammer 1998) regarding their learning needs. This study concentrated on 3 aspects in short-term courses, such as different styles of feedback, performance and communication needs in different MBTI dichotomies and because of the special context of the study (voice training), also the observation of behavioral patterns of the voice and presentation was made. Performance, in this case, means the need for checking one's own learning progress according to other MBTI dichotomies. These 3 aspects 
Katri-Liis VAINIO, Rea RAUS. Using Selected Personality Variables in a Learning Process for Holistic Education: A Case of a Voice Training Course Participants

OF EDUCATION

IN THE $21^{\text {st }}$ CENTURY

Volume 60, 2014

168 were chosen and modified from suggestions of Hanson \& Silver (1995). Each aspect of instruction offers opportunities to reach the variety of styles by changing teaching methods on a regular basis (McClanaghan 2000).

The sample of the study consisted of university teachers and lecturers, participating in the voice training course, and in the present article they are referred to as participants. The authors of the article are referred to as researchers; the main researcher was also acting as educator for the particular training course under investigation. To guarantee the reliability of the study different data collection were used and co-researcher was engaged during the whole research process.

\section{A Brief Overview of Myers-Briggs Typology Indicator (MBTI)}

The MBTI is a self-report inventory which has been used in a wide variety of settings for educational, career, and family counseling (Moore, Detlaff, \& Dietz, 2004). The instrument is based on Carl Jung's theory of psychological type and his views on perception and judgment (1927). Jung noted major differences in the way people perceived (sensation versus intuition), the way they made decisions (logical thinking versus imaginative feelings), and how active or reflective they were while interacting (extroversion versus introversion). Myers and Briggs (1977) created the Myers-Briggs Type Indicator and founded the Association of Psychological Type. They applied Jung's work and influenced a generation of researchers trying to understand specific differences in human learning. The primary feature of the theory behind the MBTI is that each person's personality fits into only one of 16 types. These categories are based on four features of personality, each consisting of two opposite preferences. According to the theory, all people have an innate preference that determines how they will behave in all situations (Pittenger, 1993), in the present case, in a learning situation. The four dimensions are:

Extroversion (E) vs Introversion (I) According to McCaulley, person's attitude or readiness to act is determined by a preference for either extraversion, which focuses on the external world, or introversion, which focuses on the internal world (McCaulley 1990).

Sensing (S) vs Intuition (N) Schoeder says, that sensing (S) versus intuition $(\mathrm{N})$ indicates whether a person prefers perceiving the world through directly observing the surrounding tangible reality or through impressions and imagining possibilities (Schroeder 1993).

Thinking $(T)$ vs Feeling $(F)$. As Kroeger and Thuesen put it, in judging or making decisions about what we have perceived, we may prefer our logical thinking (T) mode or we may prefer to make decisions based on our feelings (F) (Kroeger \& Thuesen, 1988).

Judgment (J) vs Perception $(P)$ The judgment-perception preferences were added by Briggs and Myers and it indicates whether a person has a stronger attraction toward one of the perceiving functions (sensing and intuition) or one of the judging functions (thinking and feeling) (McCaulley, 1990).

MBTI has been studied from very different points of view, relating it to managerial behaviors, such as decision making, conflict management and leadership. Evidence of relationships between psychological types and organizational roles, information systems and managerial effectiveness is also available (Fitzgerald 1997; Hammer 1996; Myers, McCaulley, Quenk \& Hammer 1998). Several studies' research management educators (Boozer \& Forte, 2004; Schullery \& Schullery, 2006), management students' learning (Fairhurst \& Fairhurst, 1995; Kise, 2007), teaching of writing domain (Jensen \& DiTiberio, 1989; Smith, 1993, 1996; Thompson, 1991, 1995, 1996, Carrell \& Monroe, 1993), technology (Chambers et al 2003; Grindler and Straton, 1990), organizational behavior and leadership sub disciplines (Clinebell 
\& Stecher, 2003), field education supervision in social work (Moore, Detlaff, \& Dietz, 2004), music (MacLellan, 2011), learning styles (Lawrence, 1997), online instruction (Harrington \& Loffredo, 2010) and grading (Fornaciari \& Lund Dean, 2013).

\section{Research Focus}

\section{MBTI instruments for specific uses}

Several researchers and educators have adapted the theory of the MBTI and developed instruments for specific uses. This study concentrates on 3 different instruments:

(1) Hanson Learning Profile Inventory (LPI) (Hanson \&Silver 1995) is a self-diagnostic assessment used to identify individual learning and teaching style preferences. The LPI measures only sensing-thinking, sensing-feeling, intuitive-thinking, and intuitive-feeling combinations of teaching/learning styles. The LPI does not include items for measuring the introversion/ extroversion classification (Carifio \& Everritt, 2007). In this article the exact case study of LPI is examined through McClanaghan's study about different learning strategies both in learning and teaching by Canter Educational Associates for Marygrove College's Master in the Art of Teaching Program (McClanaghan, 1996).

(2) David Keirsey and Marilyn Bates (Keirsey \& Bates, 1978) clustered the sixteen types of MBTI into four type groupings that they refer to as „,temperaments“(McKeen \&McSwain, 1990). The reason for this regrouping was that practicing managers argued that it is impossible for them to administer the MBTI to everyone in the workplace but without doing so, it is difficult to use the information proprietly. As counseling psychologists, Keirsey and Bates used from clinical observations of their client populations for their temperament categories.

(3) Schroeder concentrated in his study on learning characteristics of new students of Department of Student Life Studies at Saint Louis University. He stated that the understanding of learning pattern differences is further enhanced when the preferences for extroversion/ introversion and sensing/intuition are combined (Schroeder 1993).

As the present study focuses on learning process and learner individualities, the above mentioned instruments were chose for analysis.

\section{Ecological, Holistic View on Learning}

In the present article, the authors rely on the work of Stephen Sterling (2001-2011) and Gerald Grow (1991) giving us a wider conceptual and holistic framework to approach our study and Carl Jung`s and Myers-Briggs typologies to use as a methodological tool. According to ecological, holistic approach, learning educators and learners should be aware of their different abilities, potential, skills and traits to maximize learning results. By recognizing and valuing different learners, educators can plan and manage the learning process for a greater benefit of themselves and the learners. Educators are also learners as well, as learners are also educators (Sterling, 2001-2011). In the broader approach, the present study comes from the notion of sustainability. Human societies are facing diverse problems related to consumerist thinking, environmentally irresponsible, short-sighted actions, and wasteful economics. Sustainability, as a broader concept, focuses on human values and therefore, on the field of education, especially from a holistic perspective. Numerous authors have discussed the acute need to return our values, mind-sets and actions towards sustainability and sustainability education to approach 
Katri-Liis VAINIO, Rea RAUS. Using Selected Personality Variables in a Learning Process for Holistic Education: A Case of a Voice Training Course Participants

PROBLEMS

OF EDUCATION

IN THE $21^{\text {st }}$ CENTURY Volume 60, 2014

170 the learner in a more holistic way (e.g. Huckle, 1993; Bowers, 1995; Cortese, 1999; Ospina, 2000; Moore, 2005; Babiuk \&Falkenberg, 2010). Education re-shapes new, holistic thinking and practice which can lead us towards more sustainable future and learning is a critical factor here. How to support the learner (the term participant is used in the present study) in the learning process, at the same time applying a holistic approach during the whole learning process is a question. This study defines holistic education according to Stephen Sterling`s (2001-2011) ecological educational paradigm, where the terms holistic and ecological are used as synonyms. Table 1 summarizes Sterling's comparison of mechanistic and ecological educational paradigms, focusing on core values and views of learning, teaching and a learner. According to the ecological paradigm for education, a participant should be viewed as a whole person with different needs and capacities, and who has multiple intelligences. The question in this study therefore stands - how to approach a participant, who steps into the learning space and how to consider his or her individuality to enhance learning. Through inclusion and valuing all people, with their individual traits, different strengths and abilities we support participant individuality and see the benefit of including everyone into our shared and negotiated learning space.

Table 1. Comparison of mechanistic and ecological educational paradigms-core values and views of teaching, learning and a learner (Sterling, 20012011).

Learning and Pedagogy

\begin{tabular}{ll}
\hline View of teaching and learning & \\
\hline Mechanistic & Ecological/ holistic \\
\hline Transmission & Transformation \\
\hline Product oriented & Process, development, action oriented \\
\hline Emphasis on teaching & Integrative view: teachers also learners, learners also teachers \\
\hline Functional competence & Functional, critical and creative competencies valued \\
\hline View of learner & \\
\hline As a cognitive being & As a whole person with full range of needs and capacities \\
\hline Deficiency model & Existing knowledge, beliefs and feelings valued \\
\hline Learners largely undifferentiated & Differentiated needs recognized \\
\hline Valuing intellect & Intellect, intuition and capability valued \\
\hline Logical and linguistic intelligence & Multiple intelligences \\
\hline Teachers as technicians & Teachers as reflective practitioners and change agents \\
\hline Learners as individuals & Groups, organizations and communities also learn \\
\hline
\end{tabular}

According to the Table 1 above, ecological, holistic view on the whole learning process, but especially on a learner (participant), requires the appreciation of the human being as a whole person, with full range of needs and capacities. Recognizing those different needs and valuing different contributions during the learning process, by different learners, is a challenge to be handled by an educator in a professional manner. This article hopes to illuminate the way how an educator approaches the learning process in a more holistic manner. 
As adults usually come from learning environments of their past schools, being more of a „,instructed“ learner of a passive classroom (Cercone, 2008, pp. 138), then one task for the educator is to encourage participants to observe their own learning needs, strengths and weaknesses as well as reflect on themselves as independent and self-directed learners.

Educator of adults is not merely a didactical expert but more of a coach, a partner, a supporter of the individual growth and development of an adult learner. Learning process is also no longer only acquiring new knowledge and skills for specific subject, it also includes more holistic personal growth of a participant ,using“ the subject matter. So - becoming more aware of the participant's personality type is beneficial both for the education as well as for the participant him/herself. Knowing your participant, partner in a learning process for an educator and helping him/her to open his/her potential is essential to maximize learning outcomes for the learner. As Cercone (2008, pp. 151-152) states, an adult learner should be considered as a whole person, much more than a processor of cognitive information. A learner comes to a learning process with a mind and memories, feelings, beliefs, imagination, and a physical body, all of which can relate to new learning. According to her it is also important for educators to understand that culture and society influence each learner differently, where the learning process involves also learning about oneself and transforming also the way in which one learns. Myers-Briggs Type Indicator may serve as one tool for that purpose.

Adults are usually motivated but at the same time they can feel insecure with unfamiliar teaching styles and can even leave the course, if an educator fails to consider participant differences and different learning styles. According to Felder (1996), "learning styles are characteristic strengths and preferences in the way (participants) take in and process information". Felder also discusses MBTI as a learning style model. Silver, Strong, and Perini (1997) describe learning styles as showing how different ways people think and feel as they solve problems, create products, and interact. It is also about sensing, visualizing, perceiving, and learning informally with others. An educator facilitates lifelong learning when participants are motivated to learn by understanding their learning style (Coffield, Moseley, Hall, \& Ecclestone, 2004).

Today, participants usually rely on an educator's instruction during the course, mostly because they grew up with such learning-teaching styles. All learners are not independent and self-directed learners (Cercone, 2008), different participants in a learning process may need different guidance and support, also in different phases of learning. For example, according to Ausburn (2004) different learners with different characteristics benefit from different instructional features and goals. Recognizing different learning stages and learner types is a valuable resource in securing maximum learning outcomes.

\section{Methodology of Research}

\section{General Background of Research}

The main aim of the study was to find ways to support a learner (and an educator) in a holistic manner, applying MBTI (Myers-Briggs Typology Indicator) as a methodological tool to facilitate the learning process. So the research questions can be stated as follows:

1) What are the basic characters/types of participants and how the real differences appear during the course?

2) Can 3 different versions of MBTI-based grouping (Hanson Learning Profile Inventory LPI, 1995); Schroeder (1993); Keirsey \& Bates $(1978,1998)$ be revealed and used in short-term course setting? 
Katri-Liis VAINIO, Rea RAUS. Using Selected Personality Variables in a Learning Process for Holistic Education: A Case of a Voice Training Course Participants

\section{PROBLEMS \\ OF EDUCATION \\ IN THE $21^{\text {st }}$ CENTURY \\ Volume 60, 2014 \\ 172 \\ 3) Which version of MBTI-based grouping suits best to facilitate learning-teaching process?}

Qualitative and case study approach was used in the present study. Qualitative research is based on the view that reality is constructed by individuals interacting with their social worlds. As Merriam (1998:6) states, qualitative researchers are interested in understanding the meaning people have constructed, that is, how they make sense of their world and the experiences they have in the world. The research as a whole represents a case study (one course consisting of 2 modules as a case), that was both interpretive and inductive. In defining interpretive case studies, Merriam (1998, p. 38) says, that they contain rich and thick description. Inductive study relies on the study of a range of individual cases and extrapolates patterns from them to form a conceptual category"(Charmaz, 2006, p. 188). Thorough triangulation of the data helps to enhance the validity of the findings (Snyder, 2012). Creswell (1998) points out the need for triangulation in qualitative research. Defined as the "use of multiple and different sources, methods, investigators, and theories to provide corroborating evidence" (Creswell, 1998, p. 202), triangulation requires the use of several different types of data. For that purpose in the present study (1) the main researcher notes, as well as (2) videos from group reflection and (3) MBTI test results were analyzed. Data interpretation was also verified through the (4) use of main researcher/ educator note checking and improving the notes with co-researcher after every training day.

Because the main approach of the research was to find ways to help the educator to enhance learning with limited time, it was important to examine the main educator's own experiences, and these of both training modules. Especially the educator's notes about the participants from the $1^{\text {st }}$ module of the training were focused on, before participants filled in the MBTI test. The reason for that is that this is a typical situation to all educators, as in short-term courses the time to get to know the learners is limited, compared to the non-typical situation in the $2^{\text {nd }}$ module of the training, when the MBTI results were available for the educator.

So there were three sources of data in the present study - participants' self-study (including MBTI test and its reflections in group), researcher's observations of participants (including results of MBTI test) and videos from group reflection. Different sources contribute also to holistic and ecological approach to participants involved and to learning-teaching process under examination.

\section{Instrument and Procedures}

The Myers Briggs Type Indicator (MBTI) must be used ethically. Only certified professionals are qualified to administer the MBTI and interpret the results (Moore et al, 2004). The reason why this research used MBTI as a research tool was that the main educator has completed and has the certificate of the NTA (Natural Tendencies Analysis) for testing and analyzing MBTI. NTA is an analysis based on the type theory of Carl Jung, and the model is developed from the theory of MBTI. Since there is no MBTI / NTA training as such offered in Estonia, it was considered important to run this study, using the main educator as certificated MBTI professional. The English MBTI online test was used, because in testing time there was not yet any Estonian (native tongue) online version of MBTI available. Humanmetrics Jung Typology Test $^{\mathrm{TM}}$ instrument is derived from MBTI, but it uses methodology, questionnaire, scoring and software that are proprietary to Humanmetrics, and shall not be confused with the MBTI ${ }_{\text {, }}$ Myers-Briggs ${ }^{\circledR}$ and/or Myers-Briggs Type Indicator instrument offered by CPP, Inc. Humanmetrics is not affiliated with CPP, Inc. (http://www.humanmetrics.com/cgi-win/jtypes2.asp)

The free internet version was chosen also because it should be readily available and usable for future trainers. As Center for the Applications of Psychological Type (CAPT) says, all programs needing information about MBTI training and workshops, consultation, or research, as well as the cost of materials can contact them at www.capt.org. In this research it was im- 
portant to use the knowledge, gained through MBTI results, to help (1) the educator to get to know the learners better in short-term courses and (2) the learner to find his individualities. The limitations of the study clearly remain, because the aim of the study is not to use MBTI as a profound tool for psychological analysis of course participants, but merely use it as optional aid to approach different learning needs.

\section{Sample of Research}

Training was enrolled for 22 participants, of whom the final sample comprised of 15 participants, who completed the MBTI/Humanmetrics ${ }^{\mathrm{TM}}$ test. All participants were female and University teachers and educators. Because the main educator is a voice trainer, the context for the study was the voice training course. Thus, it was a convenience sample.

A request to participate in the study was submitted via e-mail for the participants at the voice training course. The objectives and procedure of the study, questionnaires and training were explained, and the participants were informed about the anonymity of their answers. The typology was discussed during group reflections and it was accepted by the participants. The disclosure of individual results of the MBTI for the purpose of discussing and reflecting the results as for deeper research of type dynamics was agreed. For ethical considerations the names of participants were coded for the purpose of the study.

The objective of the voice training was practical improvement of the voice. Therefore, the impact of the course was of crucial importance, as also to find the ways to support the whole learning process. The structure of the voice training course consisted of 2 modules, each of 2 days, in-between the modules were 27 days. Training days consisted of lectures, practical and independent work, built on body, voice and speech exercises, their analysis and video group analysis in groups, in pairs and individually. Participants prepared and presented 2 presentations in both modules, and also evaluated and gave feedback to all other participants. Video analyzing was used to reflect the learning outcomes in presentation skills. The MBTI online test was taken before the second module, to compare also learning during different modules - with and without MBTI application and with and without the educator's preliminary knowledge of the group. During the first module the educator gained a certain understanding of different learners in the group and it was possible to compare this understanding with actual test results in the beginning of second module.
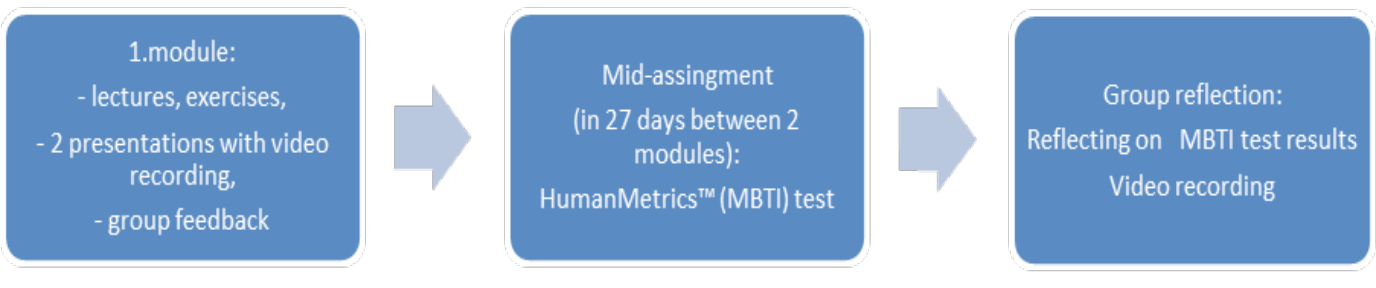

\begin{tabular}{l} 
OF EDUCATION \\
IN THE 21 $1^{\text {st }}$ CENTURY \\
Volume 60, 2014 \\
\hline 173
\end{tabular}


Katri-Liis VAINIO, Rea RAUS. Using Selected Personality Variables in a Learning Process for Holistic Education: A Case of a Voice Training Course Participants

OF EDUCAT

IN THE $21^{\text {st }}$ CENTURY

Volume 60, 2014

174

\section{Data Gathering Process}

The voice training course consisted of 2 modules. In both modules there were gathered 3 different types of data: (1) the main researcher notes of learners' improvements, (2) observations of learners by the main researcher and co-researcher, (3) video recordings of training for researchers to refresh observations and notes. Between the modules ( 27 days) there was midassignment for learners: to fill in the free English online MBTI/ Humanmetrics ${ }^{\mathrm{TM}}$ test (http:// www.humanmetrics.com/cgi-win/jtypes2.asp, 72 questions) and take the results, including percentages for each of the MBTI dichotomy, with them to the $2^{\text {nd }}$ module of the training. The results were handed to researchers. Before starting the $2^{\text {nd }}$ module of the training, the Group reflection was carried out, consisting on reflecting on MBTI test results, and notes were taken by researchers. The data was gathered also by videoing the group as observational and notes were transcribed later. Transcripts were structurised and categorised three times according to 3 MBTI instruments. The preliminary comparison of data was carried out after the $2^{\text {nd }}$ module.

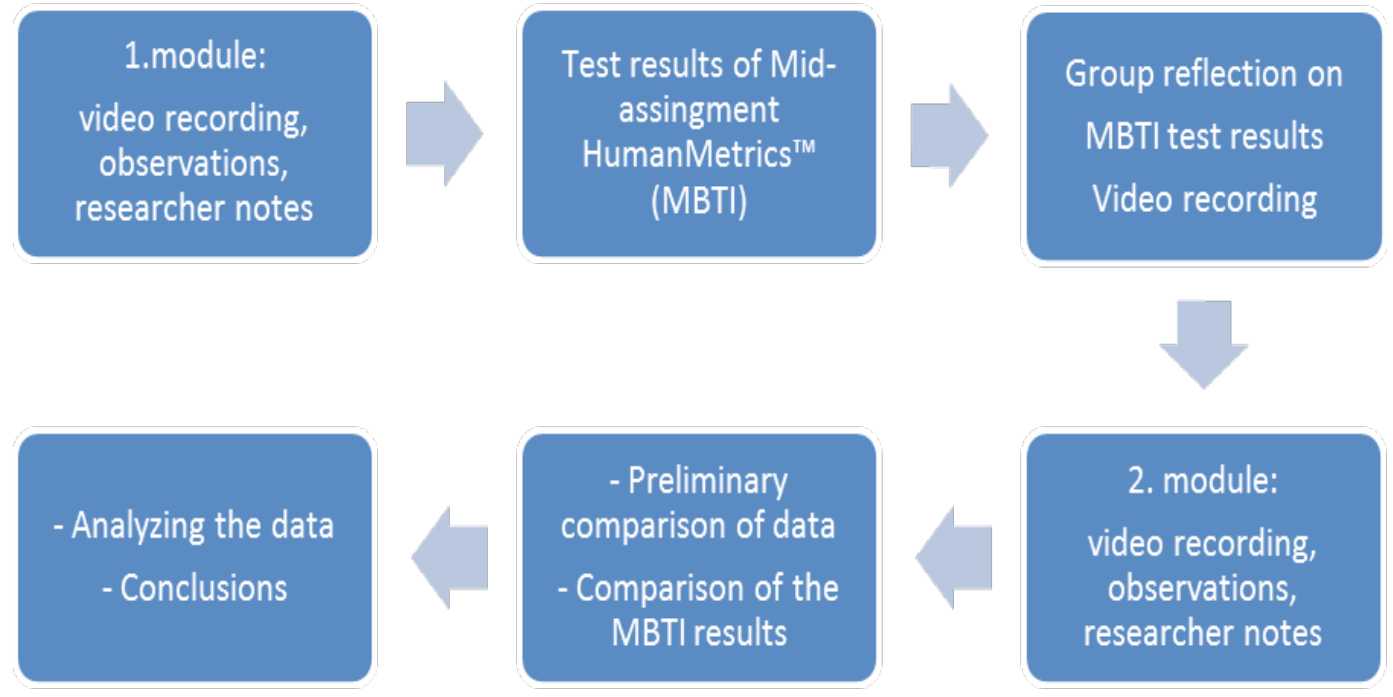

Figure 2: Data gathering process.

\section{Data Analysis}

MBTI test results were analyzed:

(1) As part of the Group reflection, together with the training group, concentrating especially in learning styles and perceiving other types, 2) Comparing the results with educator' notes from the $1^{\text {st }}$ module, (3) Comparing the data of results with different grouping versions of MBTI results to find the best compliance. Here, this study concentrated on 3 different versions: the ones of Hanson \& Silver (1995); Schroeder (1993) and Keirsey \& Bates (1978, 1998).

After analyzing the data, recommendations how to use MBTI in adult training, based on the results of the research, were made. The 3 applications were: (1) feedback, (2) performance, and (3) communication needs, when training different psychological types in short-term courses.

As the sample in the research was limited (15), the study has to be considered as a pilot study for wider research, designed according to the results of this study. 


\section{Results of Research}

According to the Humanmetrics Jung Typology Test ${ }^{\mathrm{TM}}$, as showed in Table 3: Hanson Learning Profile Inventory (LPI), the learners were divided as follows: 2 ESTJ-s (the initial letters of each of their four type preferences, Extraversion (E), Sensing, (S), Thinking (T), Judging (J); 1 ISTJ, 1 ESFJ, 1 ENFP, 1 ISFJ, 1 INFJ, 1 INFP, 2 ENTJ, 2 INTJ-s and 2 INTP-s. The main trainer was an ENFJ.

This study found 3 basic character groups/types, which were called 1) Analytical Thinker, 2) Social/Reflective Feeler 3) Holistic Visionary. The name of Analytical Thinker comes from the $3^{\text {rd }}$ letter of participants' MBTI test result (T as analytical thinking). The name of Social/Reflective Feelers comes also from the $3^{\text {rd }}$ letter of the test results (F as Feeling), and are enlarged also to encounter social/reflective areas, as these are important for feelers (Gabelnick $\&$ Pearson, 1985). The name of Holistic Visionary comes from the $2^{\text {nd }}$ letter of type results (N as Intuitive). Also, Schroeder (1993) uses the terms Visionary and Innovative which became the source of inspiration to name this group as Holistic Visionary. All these 3 character groups/ types were also divided into 2 sub-groups: Extroverts and Introverts.

\section{Analytical Thinkers (ISTJ, ISTP, ESTP, ESTJ)}

3 participants, as 2 Extroverts and 1 Introvert, belonged to this group. According to the (1) main researcher notes of learners' improvements, (2) observations of learners by the main researcher and co-researcher and (3) video recordings of training, which make the basis of discussion here, all 3 Analytical Thinkers needed very concrete explanations, arguments and reasoning, why certain exercises were needed and they were very keen on straight and concrete results. There was a big difference between 2 Extroverts and 1 Introvert in this group, as Extroverts were very active during the course and one Introvert, Analytical Thinker, was the quietest in the whole big group and very afraid of presenting. Phyl, (Holistic Extrovert) reflected on Ann's (Analytical Introvert) presentation: "You spoke so quietly, I had difficulties to hear you" and to Elisa (Analytical Extrovert) different group members gave feedback: "You are self-confident, concrete and brave". There were also other participants from other character groups with stage fright, not only Ann (Analytical Introvert). It is important to understand this difference from other stage frights, as for Ann, stage fright helped after explaining and reasoning why certain facts are important in presenting.

\section{Social/ Reflective Feelers (ISFJ, ISFP, INFJ, INFP, ESFJ, ESFP, ENFP, ENFJ)}

In this sub-group were 6 persons with 3 Extroverts and 3 Introverts. In the first module of the course Extroverts looked and sounded a lot like the Analytical Extroverts, because they also spoke with quite a quick tempo and needed to rehearse, to have slower pace in their presentation, in addition to, be more convincing. The importance of the feelings and reflectiveness of Extroverts came out merely in a closer look and on the second module of the course, where the group knew each other a little better. As also, in Analytical Thinkers' group, this Feelers' group had strong differencees between Extro- and Introverts. Social Extrovert (Karrie) had feedback from other Social Extrovert (Gerry): "You had strong, clear, and well-structurized presentation. I think you are very experienced.", as different partcipants said to Social Introvert (Kristine): "You seem nice and friendly, but you speak so quicky and unclearly, that we can't hear you so well." 
Katri-Liis VAINIO, Rea RAUS. Using Selected Personality Variables in a Learning Process for Holistic Education: A Case of a Voice Training Course Participants

LEMS

OF EDUCATION

IN THE $21^{\text {st }}$ CENTURY

Volume 60, 2014

176

Holistic Visionary Group (INTJ, INTP, ENTJ, ENTP)

In this sub-group were 6 persons with 3 Extroverts and 3 Introverts. Extroverts reminded mostly the Analytical Thinking Extroverts because of their quick speaking tempo, volume of the voice and overall activity. Specialty of Holistic Visionary Extroverts were the intensity of their presenting, the concrete, straight and intensive contact with the audience (keen eye contact, quick tempo for asking quite straight questions, active and quick use of the space of the room, e.g. coming sometimes quickly and surprisingly close to the listeners, waiting intensively for audience answers). These Extroverts were quite sure of themselves and felt for the others in the big group and for researchers like real experts of their field. Holistic Extroverts learned new information in a quick manner, i.e. putting new style into action already in the next sentences and asking feedback, if we could see the new style working for us and them (for more detail, see „Reflections of participants“, No.6., reflection of Ida). Also Holistic Introverts liked to learn through feedback and were able to adapt new information quickly, but in their cases it was connected to believing in themselves. (For more detail, see „Reflections of participants“, No 9., reflection of Tina)

\section{The difference between Extroverts and Introverts in short-term courses}

Results of this study (Table 2) show that there are differences between Extroverts and Introverts in every sub-group. For good results the educator needs to provide effective learning environment for both groups at the same time. Extroverts can learn in relatively quick tempo, in front of the others and in discussion with others, as also using others' feedback. As in new atmosphere, they like to work with other extroverts, with whom they „ping pong“ their ideas and thoughts and implement the new info quickly, if possible. Introverts need more time, they do not like, if the learning tempo is relatively quick, or the group is too big for them (sometimes already group of 5 is big for them). They need slower pace and smaller, more intimate atmosphere, which takes into consideration everyone's needs and thoughts. The slower pace in teaching is also important because they need to ,speak to themselves“, reflect the text once again in their head. In this study there could be clearly seen 2 types of people when giving feedback to the video analysis - (1) quick, straightforward Extroverts, and (2) Introverts, who answered more often after the educator had asked straightly for their answer, or they wanted to add their opinion, because, for some reasons, it seemed very important for them. 
Table 2. Results according to Vainio \& Raus (2014).

\begin{tabular}{|c|c|c|c|c|c|c|}
\hline & $\begin{array}{l}\text { Analytical } \\
\text { Extrovert }\end{array}$ & $\begin{array}{l}\text { Analytical } \\
\text { Introvert }\end{array}$ & $\begin{array}{l}\text { Feeling Extra- } \\
\text { vert }\end{array}$ & $\begin{array}{l}\text { Feeling } \\
\text { Introvert }\end{array}$ & $\begin{array}{l}\text { Holistic } \\
\text { Extravert }\end{array}$ & $\begin{array}{l}\text { Holistic } \\
\text { Introvert }\end{array}$ \\
\hline Feedback & $\begin{array}{l}\text { Need frequent, } \\
\text { straight, concret } \\
\text { Need to know if }\end{array}$ & $\begin{array}{l}\text { ick, short, } \\
\text { feedback. } \\
\text { ey are right. }\end{array}$ & $\begin{array}{l}\text { Need infrequent, } \\
\text { quick feedback, } \\
\text { with emphasis } \\
\text { on the amount } \\
\text { of effort that is } \\
\text { evidenced }\end{array}$ & $\begin{array}{l}\text { Need } \\
\text { infrequent, soft } \\
\text { feedback with } \\
\text { an emphasis } \\
\text { on its value, } \\
\text { its uniqueness } \\
\text { and creativity }\end{array}$ & \multicolumn{2}{|c|}{$\begin{array}{l}\text { Need infrequent, straight, } \\
\text { concrete feedback, with expla- } \\
\text { nation of why they received the } \\
\text { grade they did }\end{array}$} \\
\hline $\begin{array}{l}\text { Process } \\
\text { checking } \\
\text { (perform- } \\
\text { ance) }\end{array}$ & $\begin{array}{l}\text { Need for } \\
\text { checking- is } \\
\text { their perform- } \\
\text { ance soft, slow } \\
\text { enough for } \\
\text { introverts? }\end{array}$ & $\begin{array}{l}\text { Need for } \\
\text { checking- } \\
\text { is their per- } \\
\text { formance } \\
\text { interesting, } \\
\text { quick } \\
\text { enough for } \\
\text { extroverts? }\end{array}$ & $\begin{array}{l}\text { Need for check- } \\
\text { ing- is their } \\
\text { performance soft, } \\
\text { slow enough for } \\
\text { introverts? }\end{array}$ & $\begin{array}{l}\text { Need for } \\
\text { checking- is } \\
\text { their perform- } \\
\text { ance interest- } \\
\text { ing, quick } \\
\text { enough for } \\
\text { extroverts? }\end{array}$ & $\begin{array}{l}\text { Need for } \\
\text { check- } \\
\text { ing - is their } \\
\text { performance } \\
\text { slow and } \\
\text { empathetic } \\
\text { enough for } \\
\text { introverts? }\end{array}$ & $\begin{array}{l}\text { Need for } \\
\text { checking -is } \\
\text { their perform- } \\
\text { ance interest- } \\
\text { ing and } \\
\text { empathetic } \\
\text { enough for } \\
\text { introverts? }\end{array}$ \\
\hline $\begin{array}{l}\text { Commu- } \\
\text { nication } \\
\text { needs }\end{array}$ & $\begin{array}{l}\text { Need com- } \\
\text { munication } \\
\text { with others }\end{array}$ & $\begin{array}{l}\text { Need } \\
\text { written } \\
\text { information, } \\
\text { enough } \\
\text { time to un- } \\
\text { derstand it }\end{array}$ & $\begin{array}{l}\text { Need concen- } \\
\text { trating to only } \\
\text { important issues: } \\
\text { "Less is more" }\end{array}$ & $\begin{array}{l}\text { Need the } \\
\text { teacher's } \\
\text { empathetic } \\
\text { sensitivity } \\
\text { (atmosphere/ } \\
\text { feedback) }\end{array}$ & $\begin{array}{l}\text { Need high } \\
\text { degree of } \\
\text { autonomy }\end{array}$ & \\
\hline
\end{tabular}

The MBTI results can be understood and grouped in several ways. This study concentrates on 3 different versions: the one of Hanson \& Silver (Learning Profile Inventory, LPI, 1995), shown in Table 3; Schroeder (1993), shown in Table 5 and Keirsey \& Bates (1978, 1998), shown in Table 4.

The main approach of the research was to use the concept, how to help the educator with demands of effective use of the course time, which means understanding their participants from the first moment of the course, when no pre-tests or any more information about the participants of the coming course are available.

Hanson's conclusions (shown in Table 3) were most close to the results of this study, because Hanson divided learners as analytical thinkers, feelers, and innovative (intuitive) thinkers, as researchers of this study did. Hanson did not divide learners as extroverts and introverts, and this is a very important difference, because in the experience of writers of this article, the new teachers with new participants, extroverts and introverts need different instructions. This study also found that SF:s (Sensing Feelers) and NF:s (Intuitive Feelers) do not need to be divided into 2 groups- they match both to „feelers“ and need the same kind of instructions. 
Katri-Liis VAINIO, Rea RAUS. Using Selected Personality Variables in a Learning Process for Holistic Education: A Case of a Voice Training Course Participants

PROBLEMS

OF EDUCATION

IN THE $21^{\text {st }}$ CENTURY

Volume 60,201

Table 3. Hanson's Learning Profile Inventory (LPI) (1995).

\begin{tabular}{|c|c|c|c|}
\hline ST & SF & NF & NT \\
\hline ISTJ (Ann) & ISFJ (Kitty) & INFJ (Kristine) & INTJ (Ivy) \\
\hline ISTP & ISFP & INFP (Margaret) & INTP (Tina, Estelle) \\
\hline ESTP & ESFP & ENFP (Gerry) & ENTP \\
\hline ESTJ (Elisa, Mabel) & ESFJ (Karrie) & ENFJ (Katherine) & ENTJ (Ida, Phyl, Rene) \\
\hline $\begin{array}{l}\text { "What?" } \\
\text { Facts, details, linear, ana- } \\
\text { lytical aspects of thinking, } \\
\text { Logical conclusions, Learn } \\
\text { best by doing (Independ- } \\
\text { ent study) }\end{array}$ & $\begin{array}{l}\text { "What if?" } \\
\text { Facts, details } \\
\text { Trust feeling rather than } \\
\text { judgment } \\
\text { Learn best by guided study } \\
\text { (coaching) }\end{array}$ & $\begin{array}{l}\text { "Why?" } \\
\text { Deal in possibilities } \\
\text { Must have reason for } \\
\text { doing things } \\
\text { Learn best through } \\
\text { discussion }\end{array}$ & $\begin{array}{l}\text { "How?" } \\
\text { Most interested in theories, } \\
\text { building models for observed } \\
\text { phenomena } \\
\text { Learn best from } \\
\text { lecture }\end{array}$ \\
\hline
\end{tabular}

Keirsey \& Bates (See Table 4) use the letter pairs to point out four kinds of temperaments: SP, SJ, NT and NF. Thus, the 16 types could be considered as four psychological temperaments. In these conclusions there are no extroverts/introverts included, which writers of this article found not useful. The second difference was that this study found NT types using quicker tempo than other, especially when telling and structuring their ideas, although they were called Phlegmatic in Keirsey\& Bates's. The third difference showed that in Choleric temperament group the participants were more affected of their Extroversion/Introversion (from 2 introverts in this group one burst into tears and was not close at all to choleric temperament), which needs from educator to be taken care of more than the Choleric temperament.

Table 4. Results according to Keirsey \& Bates $(1978,1998)$.

\begin{tabular}{llll}
\hline SP & SJ & NF & NT \\
\hline $\begin{array}{l}\text { Dionysian temperament, } \\
\text { Artisan, Sanguine }\end{array}$ & $\begin{array}{l}\text { Epimethean temperament, } \\
\text { Guardian, Melancholic }\end{array}$ & $\begin{array}{l}\text { Apollonian temperament, } \\
\text { Idealist, Choleric }\end{array}$ & $\begin{array}{l}\text { Promethean temperament, } \\
\text { Rational, Phlegmatic }\end{array}$ \\
\hline & ESTJ (Elisa, Mabel) & INFJ (Kristine) & INTJ (Ivy) \\
\hline ISFJ (Kitty) & INFP (Margaret) & INTP (Tina, Estelle) \\
\hline ISTJ (Ann) & ENFP (Gerry) & ENTJ (Ida, Phyl, Rene) \\
\hline $\begin{array}{l}\text { Active, impulsive, light- } \\
\text { hearted }\end{array}$ & ESFJ (Karrie) & ENFJ (Katherine) & \\
\hline & ing, work ethic & Integrity, meaning, caring \\
for others & $\begin{array}{l}\text { Intelligence, competence, } \\
\text { objectivity, self- critical }\end{array}$ \\
\hline
\end{tabular}

Schroeder's results (Table 5) consider participants for the first time. Also, extroverts and introverts were divided into Sensing and Intuitive types. Unfortunately, there were no Feelers included in Schroeder's results, which this study found not useful. 
Table 5. Results according to Schroeder (1993).

\begin{tabular}{|c|c|c|c|}
\hline ES & IS & EN & IN \\
\hline Concrete active & Concrete reflective & Abstract active & Abstract reflective \\
\hline ESTJ (Elisa, Mabel) & ISTJ (Ann) & ENFP (Gerry) & INFJ (Kristine) \\
\hline \multirow[t]{3}{*}{ ESFJ (Karrie) } & ISFJ (Kitty) & ENTJ (Ida, Phyl, Rene) & INFP (Margaret) \\
\hline & & ENFJ (Katherine) & INTJ (Ivy) \\
\hline & & & INTP (Tina, Estelle) \\
\hline $\begin{array}{l}\text { Action-oriented realists, } \\
\text { The most practical of all } \\
4 \text {, Learn best when useful } \\
\text { applications are obvious }\end{array}$ & $\begin{array}{l}\text {-Thoughtful realists } \\
\text {-Preferring to deal with } \\
\text { what is real } \\
\text {-Prefer careful, unhurried } \\
\text { way }\end{array}$ & $\begin{array}{l}\text {-Action-oriented innovators } \\
\text {-having wide-range- } \\
\text { interests } \\
\text {-Liking new possibilities } \\
\text { as challenges to make } \\
\text { something happen }\end{array}$ & $\begin{array}{l}\text {-Thoughtful innovators } \\
\text {-Introspective } \\
\text {-Scholarly interested in } \\
\text { knowledge for their own } \\
\text { sake } \\
\text {-Value ideas, theory, depth } \\
\text { of understanding }\end{array}$ \\
\hline
\end{tabular}

Combining the results of this study with results of Hanson (1995), Schroeder (1993), and Keirsey \& Bates $(1978,1998)$, the writers found the conclusions of this study matching most to those of Hanson. As practical applications for practitioners, this study gained 6 different sub-groups, dividing participants into Introverts and Extraverts, Analytical Thinkers, Social/ Reflective Feelers and Holistic Visionaries (shown in Table 2).

\section{Reflections of Participants}

MBTI test was taken before the second module in this course, to compare learning during different modules -with and without MBTI application and also with the educators' preliminary knowledge of the group. During the first module the educator had a certain understanding of different participants in the group and it was possible to compare the preliminary understanding with actual test results at the beginning of the second module. Here, 9 different cases are discussed, found in 3 sub-groups (Analytical Thinker, Social/Reflective Feeler and Holistic Visionary).

\section{Analytical Thinkers sub-group}

1. Mabel: During the first module, the educator thought that Mabel (Analytical Extrovert) actually belonged to the Social/Reflective Feelers' group, and was an Introvert. The reason for this was that she looked quiet, warm and empathetic, helped with organizing, and felt more like an ISFJ. After filling the MBTI test, she was found to be an ESTJ and it became clear, why she pointed out her opinions self-confidently and strongly in her presentations, more concentrated on making clear point, than warmness, what we expected her to have. Mabel also mentioned that she forgets to „turn her voice on" for being loud enough, to be more convincing, which she found interesting.

2. Ann: (Analytical Introvert) was silent for most of the time, but when she spoke, she had always something very important to say, which made the others usually ask for her opinion. And when she spoke, the tone of her voice was strong, almost cutting. 
Katri-Liis VAINIO, Rea RAUS. Using Selected Personality Variables in a Learning Process for Holistic Education: A Case of a Voice Training Course Participants

\author{
PROBLEMS \\ OF EDUCATION \\ IN THE $21^{\text {st }}$ CENTURY \\ Volume 60, 2014 \\ 180
}

\section{Social/Reflective Feelers sub-group}

3. Kitty and Kristine: As Social/Reflective Introverts, Kitty and Kristine surprised the whole group of all participants- they burst into tears while completing their individual video exercise. The reasons could be either: "I don't want to be in front of the others", "perfectionsm", big "sensitivity"- these were their words. On the other hand, Kitty and Kristine were very satisfied with the course and told that they learnt a lot themselves. The chock that participant starts to cry can be very difficult for an educator. As Murphy $(2013$, p.4.) puts it, ,an awareness of preferences is the first step to managing learning. Self-awareness is essential to self-management. Teaching children [in this case, adults] about type differences gives them the language to explain their process of learning and development. It gives them a way to think about their learning, and such metacognition is considered as an important skill for students to develop“".

4. Kitty: Kitty volunteered to help the educator to set up the room and looked active and open (like Extrovert, e.g. ENFP), but in her presentation burst into tears „I can't do it, I'm afraid". We found out later, in the $2^{\text {nd }}$ module, that according to MBTI she was ISFJ type.

\section{Holistic Visionary sub-group}

5. Ida, Phyl, Rene: As Holistic Extroverts, Ida, Phyl and Rene had no idea, how their voice and presenting could affect more sensitive Social Introverts (Kitty, Kristine, Margaret). Kitty gave Ida feedback, how she felt: „You were so intensive and came so close, so I couldn't listen to you, I moved slightly backwards with my chair all the time“".

6.Ida: Ida's learning style was very quick, also after the words of Social Introvert (Kitty), mentioned in previous reflection (No. 5), and other feedback she was given. She processed this feedback for herself, said her apologies to introverts, and installed a new, softer, slower and less intensive speaking style in her next presentation within 5 minutes.

7. Ida, Phyl, Rene, Ivy, Tina, Estelle: Both Holistic Extroverts (Ida, Phyl, Rene) and Introverts (Ivy, Tina, Estelle) had the feeling, that they tend to jump with their thoughts into different areas and back in a very quick manner, thus affecting their presenting, explained with their words: „I felt I have lost the „red line“ in my presentation“. We as listeners, both as researchers and the other group members, as we discussed it in our group reflections, did not notice it.

8. Ivy, Tina, Estelle as Holistic Introverts had a strong inner belief that they had (in their words): ,a voice, which is not nice to hear and the presentation skills are weak“. Practical application for practitioner of this case is shown in the next section, No.5).

9. Tina as a Holistic Introvert (INTP, referred in MBTI as Introverted Intuitive Thinking and Perceiving person), who had one of the softest voices of the whole training group, was quite quiet and seemed soft, feeling and a shy person at the beginning of the first training module (like ISFJ- Introverted Sensing Feeling and Judging). After hearing her voice from the video in the end of the first module and filling in the MBTI test in-between the modules, in the group reflection at the beginning of the $2^{\text {nd }}$ module she used the words: „I look like a mouse, but feel myself like a lion". And because she looked like described before, the whole group had communicated with her like with a „mouse“, although she wanted to be taken as a „lion“. For her, the MBTI test was an eye-opener, and her last presentations were a big difference from her first ones, committed with strong voice and inspiring presenting. 
Katri-Liis VAINIO, Rea RAUS. Using Selected Personality Variables in a Learning Process for Holistic Education: A Case of a Voice Training Course Participants

\section{Practical Applications for the Practitioners}

$\mid$\begin{tabular}{l} 
PROBLEMS \\
OF EDUCATION \\
IN THE 21 $1^{\text {st }}$ CENTURY \\
Volume 60, 2014 \\
\hline 181
\end{tabular}

These applications are derived from the results of the study, and especially from the 9 reflections of participants, indicated above.

(1)Analytical Thinkers appreciate criticism and clear, straightforward feedback and are not easily offended types. The same kind of feedback could be a mistake in case of Social/ Reflective types, who could even cry if the feedback seemed too straight or critical for them.

(2)Social/Reflective Introverts will need from the facilitator the most empathetic notice as possible, such as medium (not too strong) eye contact, soft voice tone, slow speaking tempo, time for reflecting, asking for their feedback etc.

(3) An Introverted Social/Reflective Feeler is a type that must be always taken care of voice and body language, whenever giving instructions, because educators can't know the exact type of every participant, before they have filled in the MBTI questionnaire.

(4) Stage frights in Social/Reflective group will need empathetic sympathy, warmth and time to get over stage fright, which is contradictory to Analytical introvert, who needs explaining and reasoning why certain facts are important in presenting.

(5) Changing the Holistic Visionary Introverts' possible self-beliefs, based on low selfesteem in their voice and presentation skills takes time and needs video analysis from as a neutral outstand position and open positive feedback from the whole group. And, as for stage frights of this group, this self-belief is to deal with their stage fright.

\section{Discussion}

The interpretation of MBTI results should focus on helping the educators and participants respect and value the contributions of each type, while avoiding judgments based on the type (Myers, McCaulley, Quenk \& Hammer 1998; Pearman \& Albritton, 1997). In the interpretation it is important that educators understand that type is only one factor influencing choices and behavior (Carskadon, 1979; Myers et al, 1998). It should be used to help educators understand patterns of behavior associated with various types so they can respond to student learning needs and can help students learn to adapt to situations that challenge their preferences (Lawrence, 1997; Myers et al, 1998).

A final issue to consider when using the MBTI is educator's self-awareness. They must be aware of their own preferences and recognize how these preferences affect expectations of student performance. They may prefer students with specific personality types, because of the way these students perform or may unwittingly evaluate students most like them, as more successful (Moore, Jenkins \& Dietz, 1998).

\section{Conclusions}

As Murphy (2013, p.5.) puts it: „Quality education can occur when we design differences, respect development, and allow choices. Research gives us tools for designing more wisely". Writers of this article agree with Murphy, that good lessons shall provide opportunities for all types to flourish. With flexibility of instructional design all types will find success in the educational system while educators provide students a variety of approaches to help them discern their individual preferences. 
Katri-Liis VAINIO, Rea RAUS. Using Selected Personality Variables in a Learning Process for Holistic Education: A Case of a Voice Training Course Participants

PROBLEMS

OF EDUCATION

IN THE $21^{\text {st }}$ CENTURY

Volume 60, 2014

182

By recognizing and valuing different learners, educators can plan the future courses and manage the learning process for a greater benefit of ourselves and the learners. When becoming more aware of the learner's personality type, it is beneficial both for the educator as well as for the participant him/herself. Myers-Briggs Type Indicator serves as one tool for that purpose. Our study can be considered as a pilot, due to the small number of participants and a short-term nature of the study, but it enables to raise questions and offer some practical tips to plan the learning process in more holistic way. Because the research gives only preliminary conclusions, there is a need for further investigation of how to apply MBTI in different learning contexts.

\section{Acknowledgements}

The authors gratefully acknowledge support from the European Social Fund (grants no. 1.2.0401.09-0070).

\section{References}

Ausburn, L. J. (2004). Course design elements most valued by adult learners in blended online education environments: An American perspective. Educational Media International, 41 (4), 327-337.

Babiuk, G \& Falkenberg, T.(2010). Sustainable development and living through changing teacher education and teaching in Manitoba. Research Report. Manitoba University.

Bowers, C. A. (1995). Education for an ecologically sustainable culture. Rethinking moral education, creativity, intelligence and other modern orthodoxies. State University of New York Press.

Boozer, R. W., \& Forte, M. (2004). Two exercises for exploring the relationships among Jungian psychological types, organizational ideals, and organizational politics perceptions. Journal of Management Education, 28, 390-403.

Carifio, J., Everritt, A. (2007). Further validation of Hanson's learning profile indicator and Silver, Hanson, and Strong's teaching style inventory. Work, 29 (2), 165-174.

Carrell, Patricia L., \& Monroe, Laura B. (1993). Learning styles and composition. The Modern Language Journal, 77 (2), 148-162.

Carskadon, T. (1979). Clinical and counseling aspects of the Myers-Briggs type indicator: A research review. Research in Psychological Type, 2, 83-84.

Chambers, S. M., Hardy, J. C., \& Smith, B. J. (2003). Personality indicators and emergency permit teachers' willingness to embrace technology. Journal of Instructional Psychology, 30 (3), 185-188.

Charmaz, K. (2006). Constructing grounded theory: A practical guide through qualitative analysis. Thousand Oaks, CA: Sage Publications.

Cercone, K. (2008). Characteristics of adult learners with implications for online learning design. AACE Journal, 16 (2), 137-159.

Clark, C. M., \& Peterson, P. L. (1986) Teachers thought processes. In M. Wittrock (Ed.), Handbook of Research in Teaching. New York: MacMillan.

Clinebell, S., \& Stecher, M. (2003). Teaching teams to be teams: An exercise using the Myers-Briggs Type Indicator and the Five-Factor personality traits. Journal of Management Education, 27, 362383.

Cortese, Anthony, D. (1999). Education for sustainability: The university as a model of sustainability. Second Nature, Inc.

Creswell, J. W. (1998). Qualitative inquiry and research design: Choosing among five traditions. Thousand Oaks, CA: Sage Publications.

Gabelnick, F., Pearson, C. (1985). Finding their voices. Feminist Teacher, 1 (3), 11-17, 30.

Grindler, M. C., \& Straton, B. D. (1990). Type indicator and its relationship to teaching and learning styles. Action in Teacher Education, 7, 31-34.

Hammer, A. L. (Ed.). (1996). MBTI applications: A decade of research on the Myers-Briggs Type indicator. Palo Alto, CA: Consulting Psychologists Press.

Hanson, J. R., \& Silver, H. F. (1995). Learning styles and strategies. Woodbridge, N.J.: The Thoughtful Education Press.

Harrington, R., \& Loffredo, D. A. (2010). MBTI personality type and other factors that relate to preference for online versus face-to-face instruction. Internet and Higher Education, 13 (1-2), 89-95. 
Fairhurst, A. L., \& Fairhurst, L. L. (1995). Effective teaching effective learning: Making the personality connection in your classroom. Palo Alto, CA: Davies-Black.

Felder, R. M. (1996). Matters of style. Retrieved July 10, 2014 website: http://www4.ncsu.edu/unity/lockers/users/f/felder/public/Papers/LS-Prism.htm

Fitzgerald, C. (1997). The MBTI and leadership development: Personality and leadership reconsidered in changing times. In C. Fitzgerald \& L. K. Kirby (Eds.), Developing leaders: Research and applications in psychological type and leadership development, 311-336. Palo Alto, CA: Davies-Black.

Fornaciari, C. J., \& Lund Dean, K. (2013). I, S, T, and J Grading Techniques for Es, Nc, Fs, and Ps: Insights From the MBTI on managing the grading process. Journal of Management Education, 37 (6), 828-853, doi: 10.1177/1052562912461737.

Jensen, G. H., \& DiTiberio, J. K. (1989). Personality and the teaching of composition. Norwood, NJ: Ablex.

Kiersey, D. \& Bates, M. (1978). Please understand me. Del Mar, California: Prometheus Nemesis Books.

Kise, J. (2007). Differentiation through personality types: A framework for instruction. Thousand Oaks, CA: Corwin Press.

Kroeger, O., \& Thuesen. J. M. (1988). Type talk: The 16 personality types that determine how we live, love, and work. Dell Publishing, New York.

Lawrence, G. (1997). Looking at type and learning styles. Palo Alto, CA: Consulting Psychologists Press.

Love, R. (2007). Love your voice: Use your speaking voice to create success, self-confidence, and starlike charisma. Hay House, Inc.

Lyons, C. A. (1984). Consistency between learning patterns and teaching style behavior of prospective elementary teachers. A Paper Presented at the Annual Research Association. (ERIC Document Reproduction Service No. ED244396).

Ospina, G. L. (2000). Education for sustainable development. A local and international challenge. Prospects, $X X X(1)$.

MacLellan, C. R. (2011). Differences in Myers-Briggs personality types among high school band, orchestra, and choir members. Journal of Research in Music Education, 00224294, 59 (1).

McCaulley, M. (1990). The Myers-Briggs type indicator: A measure for individuals and groups. Measurement and Evaluation in Counseling and Development, 220, 181- 195.

McClanaghan, M. (2000). A strategy for helping students learn how to learn. Education, 120 (3), 479486.

McKeen, R. L., \& McSwain, C. (1990). Keirsey-Bates temperament categories: A basis for motivational interventions. Human Resource Development Quarterly, 1 (3), 237-250.

McNickle, P. J., \& Veltman, G. C. (1986). Gathering the force fields of energy in student affairs: Staff development using The Myers-Briggs Type Indicator. NASP Journal, 202-208.

Merriam, S. B. (1998). Qualitative research and case study applications in education. San Francisco, CA: Jossey-Bass Publishers.

Moore, L. S., Jenkins, D., \& Dietz, T. (1998). Adapting social work education to student diversity: The use of Myers-Briggs Type Indicator in curriculum development. Journal of Teaching in Social Work, $16(1 / 2), 179-201$.

Moore, L. S., Detlaff, A. J., \& Dietz, T. J. (2004). Using the Myers-Briggs Type Indicator in field education supervision. Journal of Social Work Education, 40 (2), 337-349.

Moore, J. (2005). Seven recommendations for creating sustainability education at the university level. International Journal of Sustainability in Higher Education, 6 (4), 326-339.

Murphy, E. (2013). Some pros, cons, and cautions about researching types is schools. Journal of Psychological Type, 73 (1), 1-6.

Myers, I., McCaulley, M. H., Quenk, N. L., \& Hammer, A. L. (1998). MBI Manual: A guide to the development and use of the Myers-Briggs Type Indicator ( $3^{\text {rd }}$ Ed.), Palo Alto, CA: Consulting Psychologists Press.

Pearman, R. R., \& Albritton, S. C. (1997). I'm not crazy. I'm not just you. Palo Alto, CA: Davies-Black Publishing.

Pittenger, David J. (1993). Measuring the MBTI... and coming up short. Journal of Career Planning \& Placement, from online website: www.indiana.edu/ jobtalk/Articles/develop/mbti.pdf

Schroeder, C. (1993). New students - new learning styles. Change, 25 (5), 21-26.

Schullery, N. M., \& Schullery, S. E. (2006). Are heterogeneous or homogeneous groups more beneficial to students? Journal of Management Education, 30, 542-556. 
Katri-Liis VAINIO, Rea RAUS. Using Selected Personality Variables in a Learning Process for Holistic Education: A Case of a Voice Training Course Participants

PROBLEMS

OF EDUCATION

IN THE $21^{\text {st }}$ CENTURY

Volume 60, 2014

184

Silver, H., Strong, R., \& Perini, M. (1997). Integrating learning styles and multiple intelligences. Teaching for Multiple Intelligences, 55 (1), 22-27.

Smith, J. B. (1993). Teachers' grading styles: The languages of feeling and thinking. Journal of Psychological Type, 26, 37-41.

Smith, J. B. (1996). Personality preferences and responding to student writing. In T. C. Thompson (Ed.), Most excellent differences: Essays on using type theory in the composition classroom, 79-89. Gainesville, FL: Center for Applications of Psychological Type.

Snyder, C. (2012). A case study of a case study: Analysis of a robust qualitative research methodology. Qualitative Report, 17.

Sterling, S. (2011) Sustainable education. Revisioning learning and change. 5th publication. Schumacher Briefings. Green Books Ltd. For The Schumacher Society.

Thompson, B., \& Borello, G. (1986). Construct validity of The Myers-Briggs Type Indicator. Educational and Psychological Measurement, 46 (3), 745-52.

Thompson, T. C. (1991). Personality type and responding to student writing: Directions for study. Retrieved from http://www.eric.ed.gov/PDFS/ED332208.pdf

Thompson, T. C. (1995). Understanding attitudes toward assessment: The personality factor. Assessing Writing, 2, 191-206.

Thompson, T. C. (1996). Understanding personality preferences and type theory. In T. C. Thompson (Ed.), Most excellent differences: Essays on using type theory in the composition classroom (pp. 1-21). Gainesville, FL: Center for Applications of Psychological Type.

Advised by Rain Mikser, Tallinn University, Estonia

Received: May 10, 2014

Accepted: July 03, 2014

MMus (Master of Musics); BA (Bachelor of Arts); Doctoral Student of the Institute of Educational Sciences of Tallinn University, Estonia, Narva mnt. 25, 10120, Tallinn.

E-mail: katriliis@luukku.com

Katri-Liis Vainio

MA Educational Sciences, Doctoral Student of the Institute of Educational Sci-

Rea Raus ences of Tallinn University, Estonia; Head of the Center for Sustainability of the Institute of Ecology, Tallinn University, M-524, Uus-Sadama 5, Tallinn, Estonia. E-mail: rearaus@tlu.ee 